Article

\title{
Interface Crystallization of Ceria in Porous Silica Films for Solar Applications
}

\author{
Gundula Helsch * and Joachim Deubener \\ Institute of Non-Metallic Materials, Clausthal University of Technology, Zehntnerstrasse 2A, \\ D-38678 Clausthal-Zellerfeld, Germany; joachim.deubener@tu-clausthal.de \\ * Correspondence: gundula.helsch@tu-clausthal.de; Tel.: +49-5323-72-2895 \\ Academic Editor: Rui M. Almeida \\ Received: 9 February 2017; Accepted: 3 March 2017; Published: 8 March 2017
}

\begin{abstract}
Antireflective (AR) coatings with photocatalytic activity for solar cover glasses are extensively investigated at present, mostly in multilayer systems including titania. In this study, bifunctional single coats from porous silica in combination with up to $33 \mathrm{~mol} \%$ ceria were prepared by sol-gel dip-coating on low-iron soda-lime float glass. After heat treatment for one hour at $350{ }^{\circ} \mathrm{C}$, the coated glasses were characterized. Solar transmittance decreased with increasing ceria content, whereas photocatalytic activity increases. Crystallization of cubic ceria was detected by grazing incidence $\mathrm{X}$-ray diffraction. Chemical depth profiling by secondary neutral mass spectrometry revealed the enrichment of cerium at the coating surface as well as at the interface to the glass substrate. Self-assembled ceria crystallization at the interfaces resulted in a three-layered mesostructure of the coating, which was verified by field-emission scanning electron spectroscopy. Cubic ceria crystals at the interface act as a barrier for the sodium diffusion from the substrate, which prevents the poisoning of the photocatalyst, while those crystals at the surface act as an electron donor for photooxidation processes, both enabling adequate photocatalytic activity. The triple-layer architecture with the sequence of high/low/high refractive index materials allows for optical interference sustaining the AR-function.
\end{abstract}

Keywords: AR-coating; porous silica; photocatalytic activity; ceria; interface crystallization

\section{Introduction}

Solar cover glasses for solar thermal applications prevent convection and radiation losses of the solar collector, and are used for thermal insulation of the solar receiver [1]. A drawback of any cover material is the loss of the incident sunlight by reflection at the surfaces of the cover sheet. Therefore, antireflective (AR) coatings (e.g., from porous silica) are applied to minimize reflection losses (e.g., see [2-5]). However, a decrease in solar transmittance, which means a decreased efficiency of the solar collector, is also caused by contaminants like volatile organic carbons or biofouling products at the surface of the cover glasses. The most investigated photocatalyst, which can oxidize and decompose organic and inorganic contaminants, is titania in the anatase modification. For solar applications, several multilayer systems with antireflective (AR) and antifouling (AF) properties, containing titania, have been investigated [6-12], and a bifunctional AR and AF single layer from dispersed $\mathrm{TiO}_{2}$ in a silica matrix has also been studied [13].

Also, ceria $\left(\mathrm{CeO}_{2}\right)$ turned out to be a promising oxide component for a combined AR and AF function since pure ceria is an n-type semiconductor with oxygen-deficient structure balancing the charge between $\mathrm{Ce}^{3+}$ and $\mathrm{Ce}^{4+}$. Labile lattice oxygen is available to catalyze oxidation processes and, thus, thin films [14-16], nanoparticles [17,18], nanosheets [19,20], hollow fibers [21], and nanorods [22] of pure and doped ceria are prepared with catalytic properties. With respect to optical properties, ceria 
nanoparticles, like titania nanoparticles, are highly refractive, and therefore they have been used to tune the refractive index of polymer thin films up to 1.95 [23].

Coatings from ceria in combination with silica are, so far, only developed as corrosion inhibitors for metals such as alumina alloy [24] and zinc [25], and as a barrier preventing sodium diffusion (from soda-lime substrate glasses) into functional coatings [26]. The combination of the photocatalytic activity of ceria with the antireflectivity of a porous silica layer for solar applications is, to the best of our knowledge, not investigated yet.

This study is further motivated by the specific crystallization of amorphous ceria in thin films. Firstly, amorphous ceria crystallizes in the form of a single high-temperature-stable cubic polymorph. Size- and temperature-dependent transformation kinetics from low- to high-temperature polymorphs, such as observed in titania [6-27], are lacking. Secondly, the crystallization of ceria prepared by precipitation-based film processing is known to undergo a double-stage transformation process, showing biphasic amorphous-crystalline nanostructures of isolated grains at the first stage [28,29]. Solvent molecules are found to slow down the transition to the second stage, while Oswald ripening is observed after establishing cluster contacts [30]. It is expected that mixing ceria sols with silica sols will further stabilize an isolated ceria grain structure in the coating. Finally, ceria is known to act as a photocatalyst under visible light radiation $[18,21]$, which can enhance self-cleaning properties of solar cover glasses if added to AR coating materials.

We report, therefore, a compositional study on the effect of ceria additions to a sol-gel-derived porous silica coating on glass. We will show that ceria crystallizes unexpectedly at low temperatures $\left(140{ }^{\circ} \mathrm{C}\right)$ at the interface and surface of the coating, which leads to a beneficial three-layered mesostructure and a combined AR and AF function of single coat.

\section{Results}

Coated solar glasses (soda-lime silicate), as prepared by dipping in Ce-bearing silica sol, were characterized by various optical and microstructural methods. UV-Vis-NIR transmittance of the ceria-silica coats was measured to explore their AR function, but also UV-A radiation was used to test the degradation capacity of a model contaminant (stearic acid) at their surface. Both properties could be traced to the structure of the coatings, which was studied by grazing incidence X-ray diffraction (GIXRD) and secondary neutral mass spectrometry (SMNS). Six different coatings were prepared and, according to their ceria molar fraction of $0,5 \%, 10 \%, 17 \%, 25 \%$, and $33.3 \%$, were identified as $0-100,5-95,10-90,17-83,25-75$, and 33-67, respectively. Standard curing of the layer was done at $350{ }^{\circ} \mathrm{C}$ for $60 \mathrm{~min}$. It is shown that self-assembly of ceria crystals at the interference and surface of the 17-83 coating contributes to a gain in solar transmittance of $3.2 \%$ and degrades the applied stearic acid film under UV-A radiation by half in about $30 \mathrm{~min}$.

\subsection{Transmittance by $U V-V i s-N I R$ Spectroscopy}

The transmittance spectra of silica coatings with ceria concentrations of 10, 17, and $25 \mathrm{~mol} \%$, compared to uncoated solar glass, are shown in Figure 1. All coatings have their transmittance maximum at around $\lambda=550 \mathrm{~nm}$, which means that the refractive index $n$ and coating thickness $d$ met the phase condition $n \times d=\lambda / 4$ for this wavelength. The pure silica coating $0-100$ increases the maximum transmittance of the solar glass from $91 \%$ up to more than $99 \%$ at $550 \mathrm{~nm}$, which indicates that the porosity of the coating is approximately $38 \%$ [5]. Increasing ceria contents from $5 \%$ to $25 \%$ led to a decreasing transmittance maximum, from $99 \%$ to $95 \%$. A second effect of ceria is a red-shift of the UV-edge due to its bandgap energy of $3.1 \mathrm{eV}$ [15]. Taking the 25-75 coating as an example and the wavelength of $50 \%$ transmittance, the UV-edge is shifted by $30 \mathrm{~nm}$, from 310 to $340 \mathrm{~nm}$. Depending on ceria concentration, the UV-transmittance (weighted air mass (AM) 1.5 average value in the UV-A and UV-B range from 280 to $380 \mathrm{~nm}$ ) reduces drastically (Table 1). The UV-transmittance of the pure silica coating $0-100$ is decreased from $84 \%$ to $73 \%$ for the $10-90$ coating and to $67 \%$ for the $17-83$ coating. Because the UV transmittance of Ce-containing films is very sensitive to the coating 
thickness, the uncertainty in the measurement is increasing with increasing ceria content to about $\pm 5 \%$ for the 33-67 coating. The solar transmittance (weighted AM 1.5 average value in the wavelength range from 300 to $2500 \mathrm{~nm}$ ) decreases from $95.7 \%$ for the pure silica coating to $93.7 \%$ for the $17-83$ coating, whereas the uncoated solar glass has a solar transmittance of $90.3 \%$. The individual transmittance values of the coatings and the uncoated solar glass are listed in Table 1.

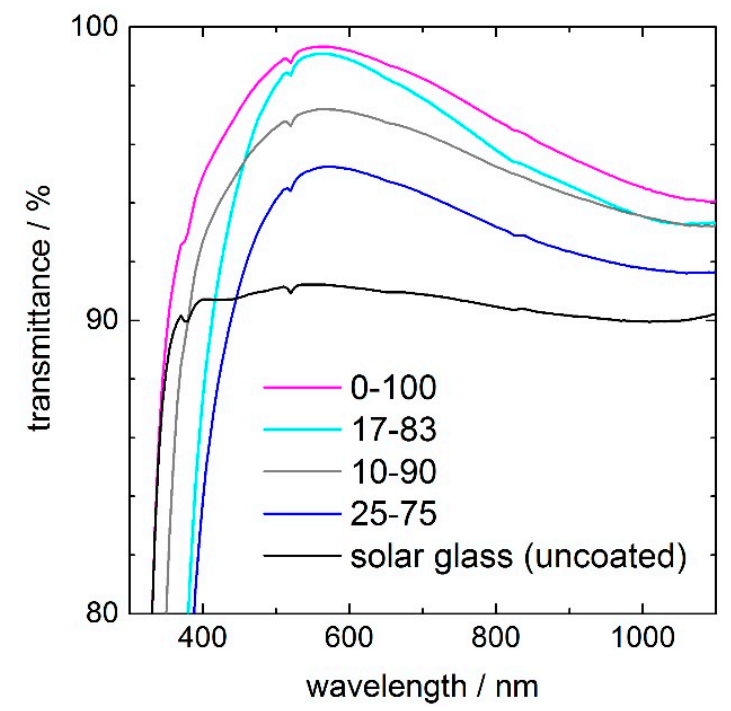

Figure 1. UV-Vis-NIR transmittance spectra of antireflective (AR) coatings from porous silica, containing 10, 17, and $25 \mathrm{~mol} \% \mathrm{CeO}_{2}$, on low-iron soda-lime glass in comparison to uncoated glass. Curing conditions were $60 \mathrm{~min}$ at $350{ }^{\circ} \mathrm{C}$.

Table 1. Solar transmittance, UV-transmittance, and thickness of porous ceria-silica coatings. Solar transmittance and UV-transmittance are weighted ( $\mathrm{AM}=1.5)$ average values of the wavelength range 300-2500 $\mathrm{nm}$ and 280-380 nm, respectively (standard procedure DIN EN 410). Numbers in parentheses indicate uncertainty of the last digit.

\begin{tabular}{cccc}
\hline Coating & Solar Transmittance (\%) & UV Transmittance (\%) & Thickness (nm) \\
\hline solar glass (uncoated) & $90.3(1)$ & $83.0(1)$ & - \\
$0-100$ & $95.7(1)$ & $84.0(1)$ & $120(5)$ \\
$5-95$ & $95.0(1)$ & $78(1)$ & $120(5)$ \\
$10-90$ & $94.2(1)$ & $76(2)$ & $120(5)$ \\
$17-83$ & $93.5(1)$ & $67(3)$ & $120(5)$ \\
$25-75$ & $91.7(1)$ & $47(4)$ & $120(5)$ \\
$33-66$ & $88.7(1)$ & $36(5)$ & $140(5)$ \\
\hline
\end{tabular}

\subsection{Crystalline Nature by Grazing Incidence X-ray Diffraction (GIXRD)}

Figure 2 shows the $X$-ray-diffraction pattern of the ceria-containing silica coatings after curing at $350{ }^{\circ} \mathrm{C}$ for $60 \mathrm{~min}$. The peaks corresponding to the (111), (200), (220), and (311) planes of fluorite structured cubic ceria at approximately $28^{\circ}, 33^{\circ}, 47^{\circ}$, and $57^{\circ} 2 \theta$ (PDF card 98-019-2224) are clearly identified. The fraction of crystalline ceria is increasing with increasing cerium content in the coating. 


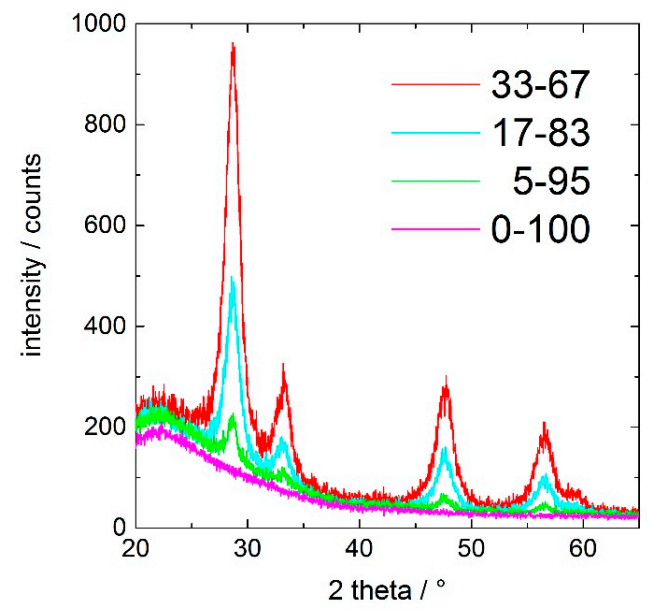

Figure 2. Grazing incidence X-ray diffraction (GIXRD) patterns of porous silica coatings with 5, 17, and $33 \mathrm{~mol} \% \mathrm{CeO}_{2}$ on low-iron soda-lime glass. Curing conditions were $60 \mathrm{~min}$ at $350{ }^{\circ} \mathrm{C}$.

In order to reveal the onset of the ceria crystallization, a freshly dip-coated, unheated 17-83 coating was studied in situ in a high-temperature chamber by GIXRD with a heating rate of $10 \mathrm{~K} / \mathrm{min}$. Figure 3 shows that the coating heated up to $100{ }^{\circ} \mathrm{C}$ remains amorphous, while that treated at higher temperatures results in the presence of cubic ceria crystals. The onset of crystallization is detected for a thermal treatment at $140^{\circ} \mathrm{C}$, and crystallization of the ceria fraction seems to be completed, as inspected from the peak heights, at $160^{\circ} \mathrm{C}$. Using Scherrer equation and the full width at half-maximum of the (111) peak of Figure 3, the size of the crystal domains were estimated to be ca. $5.5 \mathrm{~nm}( \pm 0.5 \mathrm{~nm})$ for 160 and $350{ }^{\circ} \mathrm{C}$.

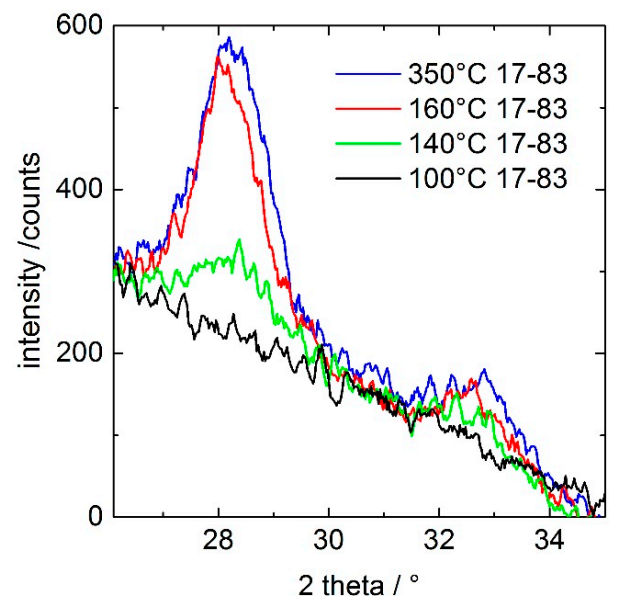

Figure 3. Evolution of the (111) and (200) diffraction peaks of cubic ceria (at approximately $28^{\circ}$ and $33^{\circ} 2 \theta$ ) during in situ GIXRD in a high-temperature chamber heated at $10 \mathrm{~K} / \mathrm{min}$ from room temperature up to $350{ }^{\circ} \mathrm{C}$.

\subsection{Chemical Depth Profiling by Secondary Neutral Mass Spectrometry (SNMS)}

Figure 4 shows the concentration depth profiles of oxygen $(\mathrm{O})$, silicon $(\mathrm{Si})$, cerium (Ce), sodium $(\mathrm{Na})$, and calcium $(\mathrm{Ca})$ of the 17-83 coating. Whereas the sputter rate for the glass substrate is $0.3 \mathrm{~nm} \cdot \mathrm{s}^{-1}$, the sputter rate for the porous layer is $0.5 \mathrm{~nm} \cdot \mathrm{s}^{-1}$. After a sputter time of $240 \mathrm{~s}$, corresponding to $120 \mathrm{~nm}$, the coating is removed. In order to reveal details of the minor fraction cerium, the concentration axis of Figure 4 is shown in logarithmic scales. For the depth profile of $\mathrm{Ce}$, a double peak in the coating with maximum intensities at $50 \mathrm{~s}(25 \mathrm{~nm})$ and $170 \mathrm{~s}(85 \mathrm{~nm})$ and a minimum intensity at $110 \mathrm{~s}(55 \mathrm{~nm})$ is evident. At the depth of the minimum of the Ce-double peak, silicon shows 
a maximum in the intensity, which indicates a $\mathrm{CeO}_{2} / \mathrm{SiO}_{2} / \mathrm{CeO}_{2}$-rich layered structure of the coating after curing at $350^{\circ} \mathrm{C}$ for $60 \mathrm{~min}$. This triple-layer structure consists of two ceria-rich layers, one at the coating/air interface, the other at the coating/glass interface, and a silica-rich layer between.

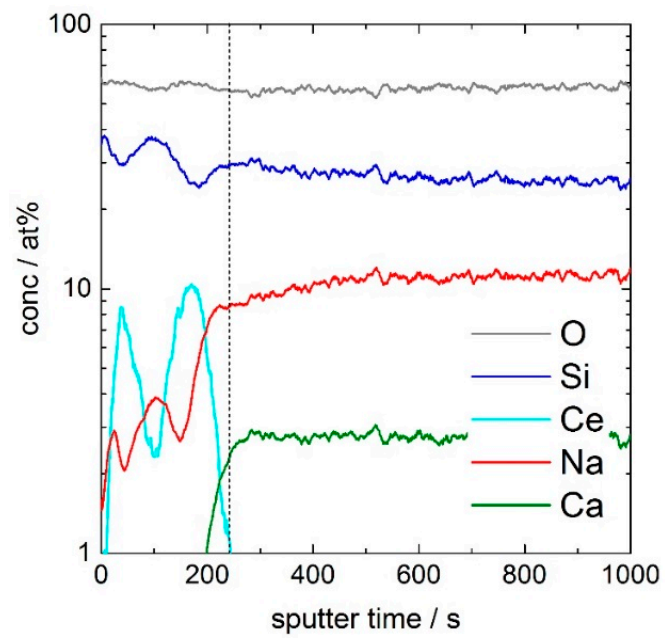

Figure 4. Secondary neutral mass spectrometry (SNMS) depth profile of the elements: oxygen (O), silicon ( $\mathrm{Si}$ ), cerium (Ce), sodium ( $\mathrm{Na}$ ), and calcium (Ca) of the 17-83 coating on low-iron soda-lime glass. Vertical dashed line at $240 \mathrm{~s}$ indicates the interface of the coating and the substrate glass. Curing conditions were $60 \mathrm{~min}$ at $350{ }^{\circ} \mathrm{C}$.

Figure 5 shows the evolution of the Ce-depth profile with increasing ceria concentration of the $120 \mathrm{~nm}$ porous silica coating. Whereas in the 5-95 coating a Ce concentration of less than 2 atom \% is nearly homogeneously distributed in the whole layer, the 10-90 coating shows an enrichment up to 6 atom $\%$ at the interface to the glass substrate. In the more Ce-rich coatings, a Ce double-peak is built up to 10 and 12 atom \% in the 17-83 and 25-75 coating. For the coating with $33 \mathrm{~mol} \%$ $\mathrm{CeO}_{2}$, the concentration of $\mathrm{Ce}$ is up to 16 atom \%, but the double peak seems to be less separated. Not shown, but also measured, was a $250 \mathrm{~nm}$ porous silica layer with $17 \mathrm{~mol} \% \mathrm{CeO}_{2}$, where the double peak was clearly pronounced with minimum and maximum Ce concentrations of 1 and 10 atom \%. Furthermore, it can be noted that the height ratio of the two Ce maxima is shifting, depending on the ceria concentration.

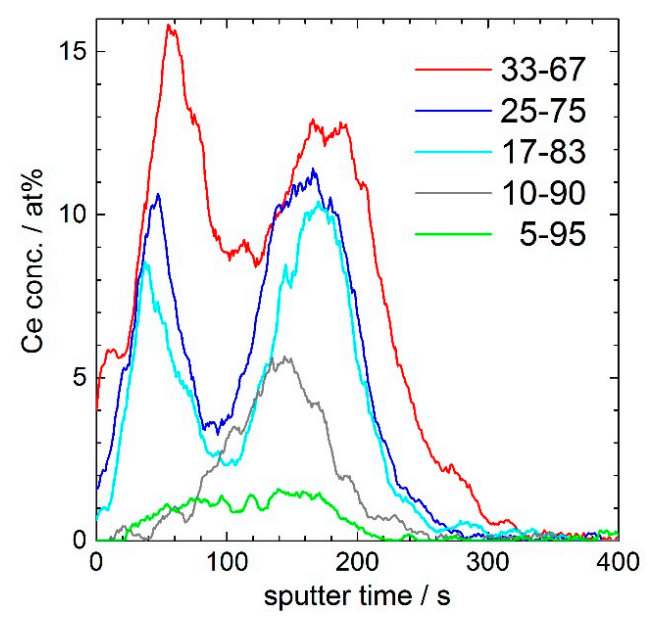

Figure 5. Comparison of the Ce-concentration depth profiles in porous silica coatings with 5, 10, 17, 25, and $33 \mathrm{~mol} \% \mathrm{CeO}_{2}$. Curing conditions were $60 \mathrm{~min}$ at $350{ }^{\circ} \mathrm{C}$. 
Figure 6 shows that the Na hump located at the second Ce maximum (close to $170 \mathrm{~s}$ sputter time, i.e., at $85 \mathrm{~nm}$ depth) is vanishing, and the average sodium concentration in the layer is decreasing with increasing ceria concentration of the coating. In the porous silica layer without ceria, the Na-enrichment is up to 16 atom $\%$, in the 5-95 coating up to 10 atom $\%$, and in the 17-83 coating Na shows a relative smooth depth dependence with a maximum value of less than 4 atom \%. This development can be explained by the assumption that the diffusion of sodium ions from the glass substrate into the layer is blocked by ceria.

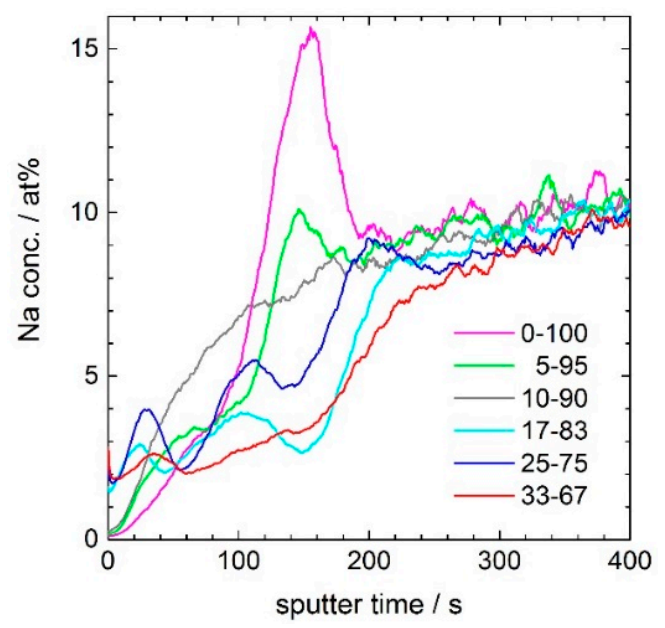

Figure 6. Comparison of the Na-concentration depth profiles in porous silica coatings with 5, 10, 17, 25, and $33 \mathrm{~mol} \% \mathrm{CeO}_{2}$. Curing conditions were $60 \mathrm{~min}$ at $350{ }^{\circ} \mathrm{C}$.

\subsection{Nanostructure by Field-Emission Scanning Electron Microscopy (FESEM)}

Figure 7 shows a micrograph (backscattered electrons) of the surface of a fractured cross-section of the 17-83 coating. The chemical contrast between the lighter Si atoms (dark) and the heavier Ce atoms (bright) is clearly indicated in the backscattering mode. The FESEM image confirms the sequence of a $\mathrm{CeO}_{2} / \mathrm{SiO}_{2} / \mathrm{CeO}_{2}$-rich layered structure of the coating with ceria crystals at the interfaces to the air and to the glass substrate, as proved by the SNMS and GIXRD data. The size of the ceria crystals is estimated from the bright regions of Figure 7 to be in the range from 20 to $40 \mathrm{~nm}$.

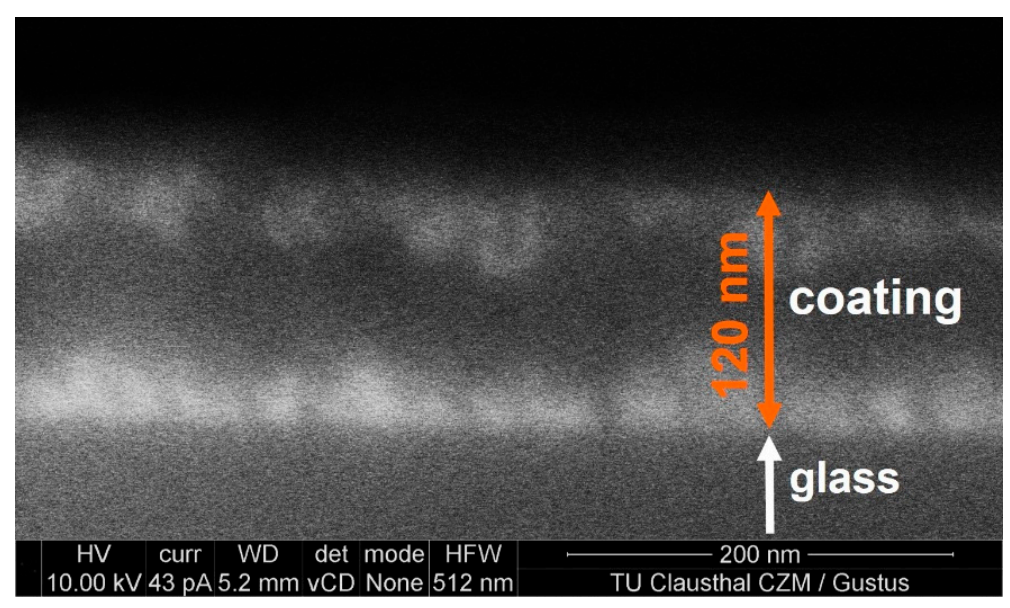

Figure 7. Fracture surface of the 17-83 coating on low-iron soda-lime glass by backscattered electron imaging (FESEM). The location of the heavier ceria crystals is indicated by the brighter regions in the image. 


\subsection{Photocatalytic Activity by Degradation of a Stearic Acid Film}

Figures 8 and 9 show the characteristic absorption bands of the $\mathrm{CH}_{2}$-stretching modes at 2853 and $2923 \mathrm{~cm}^{-1}$ of a stearic acid film on a ceria-containing coating before and after UV-A irradiation. Figure 8 compares the stearic acid degradation during $1 \mathrm{~h}$ of UV-A irradiation of the 5-95, 10-90, and 17-83 coating. An increase in the photocatalytic activity with increasing ceria content is evident. In particular, the 17-83 coating nearly completely degrades the stearic acid film during $1 \mathrm{~h}$ of UV-A irradiation, while the 10-90 coating reduces the IR peaks to approximately half. For the 5-95 coating, the stearic acid degradation is lower, but clearly visible if one compares the bands with their heights before UV-A irradiation.

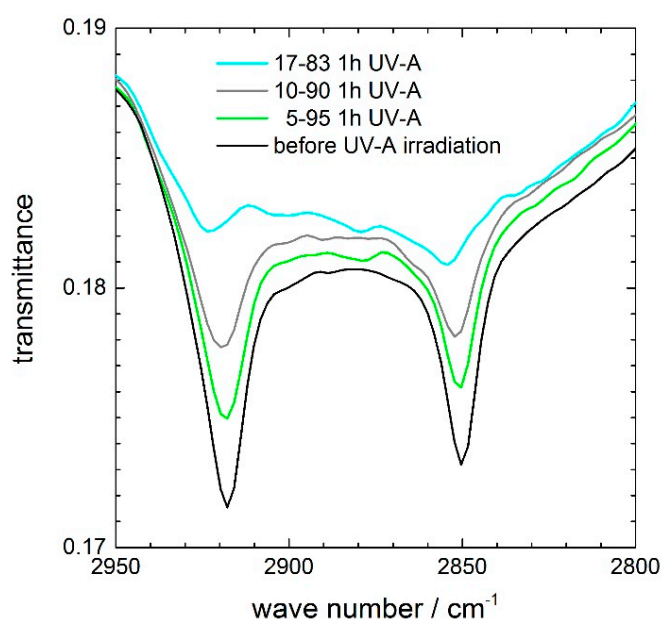

Figure 8. IR-absorption bands of the symmetric stretching modes of the $\mathrm{CH}_{2}$ group at 2923 and $2853 \mathrm{~cm}^{-1}$ of a stearic acid film on $120 \mathrm{~nm}$ porous silica coatings containing 5, 10, and $17 \mathrm{~mol} \% \mathrm{CeO}_{2}$ on low-iron soda-lime glass before and after $1 \mathrm{~h}$ of UV-A irradiation.

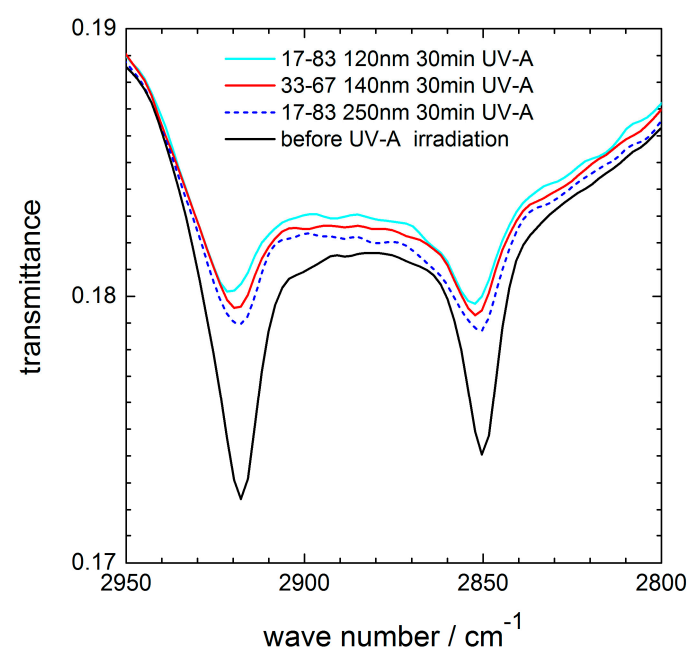

Figure 9. IR-absorption bands of the symmetric stretching modes of the $\mathrm{CH}_{2}$ group at 2923 and $2853 \mathrm{~cm}^{-1}$ of a stearic acid film on $\mathrm{CeO}_{2}$-containing porous silica coatings of 120, 140, and $250 \mathrm{~nm}$ thickness on low-iron soda-lime glass before and after $30 \mathrm{~min}$ of UV-A irradiation. $\mathrm{CeO}_{2}$ concentration was $17 \mathrm{~mol} \%$ for the 120 and $250 \mathrm{~nm}$ coating and $33 \mathrm{~mol} \%$ for the $140 \mathrm{~nm}$ coating.

For coatings with 25 (not shown) and $33 \mathrm{~mol} \%$ ceria, the same photocatalytic activity was found as for the 17-83 coating. Also, an increased thickness $(250 \mathrm{~nm})$ of the 17-83 coating did not result in an increased stearic acid degradation. These effects are displayed in Figure 9, which shows exemplarily the 
characteristic absorption bands of the $\mathrm{CH}_{2}$-stretching modes before and after 30 min UV-A irradiation for $120 \mathrm{~nm}$ and $140 \mathrm{~nm}$ thick coatings containing 17 and $33 \mathrm{~mol} \%$ ceria, respectively, and for a $250 \mathrm{~nm}$ thick coating with $17 \mathrm{~mol} \%$ ceria. Within the accuracy of the measurements, no differences in the photocatalytic activity were detected. For comparison, the photocatalytic activity of a pure silica coating 0-100 (not shown) was also investigated, but no decrease of the stearic acid absorption bands was measured within 30 or 60 min of UV-A irradiation.

\section{Discussion}

The most striking feature of this study is the self-assembled ceria crystallization at the interfaces, which resulted in a three-layered architecture of the coating. It is known from precipitation-based film processing that ceria tends to show nanostructures of isolated grains [28,29]. Segregation of ceria clusters are stabilized by solvent molecules, which hinder cluster contacts and further grain growth by Oswald ripening [30]. If one assumes that in the prepared cerium-bearing suspensions hydrated $\mathrm{CeO}_{2}$ - and $\mathrm{SiO}_{2}$-colloids are present, a "convective assembly" during withdrawal of the glass substrate and evaporation of the solvent might be possible [31]. In particular, a two-step mechanism is reported in which colloidal aggregation is first initiated by attractive capillary forces, which are balanced in the solvent meniscus between the ordering nanoparticles at the drying front. Secondly, evaporation of the solvent from the already ordered regions causes a convective flux of particles towards the drying particle layer from the bulk of the colloidal suspension [32]. Attractive capillary forces of nanoparticles depend on size, shape, and surface charge density. The surface charge of colloidal nanoparticles is often characterized by their zeta potential $\zeta$ (i.e., the electrostatic potential difference between the solvent and the stationary layer of ions attached to the dispersed particles). In aqueous suspensions $(\mathrm{pH} \geq 3)$ amorphous silica nanoparticles exhibit high negative $\zeta$ values. The point of zero charge PZC-that is, the $\mathrm{pH}$ at which $\zeta$ is zero-is found at 2.6 [33,34]. Also, in case of the soda-lime substrate glass, a high negative surface charge is reported (PZC $=2.8$, [35]). In contrast to the negatively charged surfaces of the silica-based materials, initial $\zeta$ values of ceria nanoparticles are positive (PZC $=9.5,[36])$ when the $\mathrm{pH}$ of the suspension is less than the PZC. Thus, attractive forces of oppositely charged surfaces can lead to a preferential attachment of ceria nanoparticles at the soda-lime glass substrate and at amorphous silica particles of the drying colloidal suspension. The strong ceria-silica interaction is assumed to contribute to the formation of the observed layered mesostructure of the coating. On the other hand, if one assumes that in the sol hydrated cerium complexes are present, their thermal migration during heat treatment may lead to the formation of the three-layered structure. The crystallization of ceria at $140-160{ }^{\circ} \mathrm{C}$ (Figure 3 ) shows that this migration has to be completed at even lower temperatures. However, further investigations are needed to clarify the mechanism in detail, which is beyond the scope of this study.

Due to this three-layered architecture the intended coating properties-antireflectivity and photocatalytic activity-are supported by different mechanisms. Generally, the combination of interference layers with a high refractive index for the first layer and a low refractive index for the second layer results in high antireflective properties. Depending on coating thickness, a third high refractive layer can broaden or sharpen the transmittance maximum. Regarding to SNMS (Figure 5) and FESEM (Figure 7), the top layer of sample 17-83 seems to be smaller, and it seems to contain less ceria than the layer at the interface to the glass substrate, which can explain the evolution of the transmittance curve in Figure 1. Compared to sample 10-90, whose ceria depth profile shows no double peak, the transmittance maximum is increased to between 450 and $1000 \mathrm{~nm}$, but decreased for higher and lower wavelengths. Such a wavelength dependence is typical for interference multilayers. As to be expected, and with respect to the ceria concentration, the solar transmittance of sample 17-83 is lower than that of sample 10-90.

The photocatalytic activity of the samples 5-95 and 10-90, which do not show a three-layered structure, is much lower than the activity of the three-layered samples 17-83, 25-75, and 33-67. Due to the enrichment of ceria in the top of the coating, the $\mathrm{CeO}_{2} / \mathrm{SiO}_{2}$ ratio will be much higher than in the 
coating solution prepared. Calculating with 8,10 , and 16 atom \% Ce (Figure 5), the concentration in the top layer will be 24,30 , and $48 \mathrm{~mol} \% \mathrm{CeO}_{2}$ for the samples 17-83, 25-75, and 33-67, resulting in high photocatalytic activity.

Figure 6 shows that the crystallization of cubic ceria at the interface with the substrate glass reduces the concentration of sodium ions in the coating. Sodium ion migration during thermal treatment is known to poison photocatalysts through chemical reaction. In the case of titania, sodium titanate is formed, which does not have photocatalyst function [37]. Therefore, the photocatalytic activity of a titania coating on soda-lime glass is not high. Frequently, a thin silica layer is deposited between the photocatalyst and the soda-lime substrate glass in order to prevent sodium diffusion in the coating [38]. In the case of the ceria-bearing coatings of this study, it seems that the $\mathrm{CeO}_{2}$-rich inner layer acts as a sodium barrier in a similar way by preventing the formation of electron-hole recombination center through sodium migration into the surface of the ceria nanocrystals located at the top of the coating. In addition, the $\mathrm{SiO}_{2}$-rich center layer may contribute to the Na-barrier function. A decreased oxidation of alkyl radicals for sodium-doped ceria compared to undoped ceria is reported by Kennedy et al. [39]. Further investigations clarifying the effect of sodium doping on the photocatalytic activity of ceria nanocrystals are lacking in literature. However, we assume that blocking the sodium diffusion supports the photocatalytic activity of the sample.

\section{Materials and Methods}

\subsection{Sample Preparation}

The samples were prepared by sol-gel dip-coating. Therefore, a commercial silica sol (Köstrosol ${ }^{\circledR} 2040$, Bad Köstritz, Germany) with $20 \mathrm{~nm}$ sized silica particles was diluted with 2-propanol to receive a silica concentration of $3.6 \mathrm{wt} \%$, while a $\mathrm{pH}=1$ was adjusted by nitric acid $(65 \%$, Sigma Aldrich, Munich, Germany). A $0.75 \mathrm{M}$ solution of cerium nitrate hexahydrate $\left(\mathrm{Ce}\left(\mathrm{NO}_{3}\right)_{3} \cdot 6 \mathrm{H}_{2} \mathrm{O}\right.$, 99\% Sigma Aldrich) in 2-propanol was added to the silica sol solution to receive 5, 10, 17, 25, and $33 \mathrm{~mol} \% \mathrm{CeO}_{2}$ relative to $\mathrm{SiO}_{2}$. Low-iron soda-lime glass ( $3 \mathrm{~mm}$ float glass) was coated on both sides by dipping and a withdraw speed of $1 \mathrm{~mm} \cdot \mathrm{s}^{-1}$. To get thicker coatings for comparison, a coating speed of $4 \mathrm{~mm} \cdot \mathrm{s}^{-1}$ was used additionally in the case of $17 \mathrm{~mol} \% \mathrm{CeO}_{2}$. After drying at room temperature, the samples were heated in air at $10 \mathrm{~K} \cdot \mathrm{min}^{-1}$ to $350{ }^{\circ} \mathrm{C}$, dwelled for $1 \mathrm{~h}$ at $350{ }^{\circ} \mathrm{C}$, and cooled down in the closed furnace.

\subsection{UV-Vis-NIR Transmittance}

The transmittance of the coated glass sheets was measured between 190 and $3000 \mathrm{~nm}$ by a Perkin Elmer Lambda 950 UV/Vis/NIR spectrometer (Perkin Elmer, Waltham, MA, USA) equipped with an integrating sphere $(150 \mathrm{~mm})$. The solar transmittance as well as the UV-transmittance were calculated according to DIN EN 410.

\subsection{Grazing Incidence X-ray Diffraction}

By grazing incidence X-ray diffraction (GIXRD), the crystalline phases in the thin films were identified (Empyrean, Panalytical). To get information of the thin films, $2 \theta$ scans of the diffracted beam were carried out with a step size of $0.03^{\circ} 2 \theta$, whereas the angle of the incident beam was fixed at $0.3^{\circ}$. At room temperature, the time per step was $5 \mathrm{~s}$, measured with a Xe proportional detector. In situ measurements were carried out in a high-temperature chamber (Anton Paar, Graz, Austria) with a heating rate of $10 \mathrm{~K} / \mathrm{min}$ under ambient conditions. To reduce the time of measurement in the heating chamber, a PIXcel1D detector (Panalytical, Almelo, The Netherlands) was used with 2 s per step. 


\subsection{Secondary Neutral Mass Spectrometry}

Chemical depth profiles of the coatings were measured by a secondary neutral mass spectrometer (SNMS) INA-X from Specs GmbH (Berlin, Germany), operated in the high-frequency mode. A sample area of $5 \mathrm{~mm}$ in diameter, given by a copper mask, was sputtered with a krypton plasma.

\subsection{Field-Emission Scanning Electron Microscopy}

For high-resolution imaging of the film structure, a Helios NanoLab $600\left(\mathrm{FEI}^{\mathrm{TM}}\right.$, Eindhoven, The Netherlands) field-emission scanning electron microscope (FESEM) was used. Backscattered electron images were used to analyze the chemical composition of the coating from fractured surfaces.

\subsection{Coating Thickness}

For measuring the coating thickness, the freshly prepared, unfired coating was scratched with a plastic knife without damaging the substrate. After heat treatment, the depth of the scratches was measured by profilometry using a Tencor P-1 Long Scan Profiler (Tencor Instruments, CA, USA). The accuracy of the method is $\pm 5 \mathrm{~nm}$.

\subsection{Photocatalytic Activity}

The photocatalytic activity of the coating was characterized by the degradation of a stearic acid film. Therefore, coated glass samples were dip-coated with a solution of $0.5 \mathrm{wt} \%$ stearic acid in 2-propanol using a coating speed of $2 \mathrm{~mm} \cdot \mathrm{s}^{-1}$. Characteristic peaks of the asymmetric $\mathrm{C}-\mathrm{H}$ stretching mode of the $\mathrm{CH}_{3}$ group at $2958 \mathrm{~cm}^{-1}$ and the symmetric stretching modes of the $\mathrm{CH}_{2}$ group at 2923 and $2853 \mathrm{~cm}^{-1}$ of the stearic acid $\left(\mathrm{CH}_{3}\left(\mathrm{CH}_{2}\right)_{16} \mathrm{COOH}\right)$ [40] were detected by IR-transmittance spectroscopy using a Bruker Vertex 70 FT-IR spectrometer (Bruker Optics, Ettlingen, Germany). UV-A irradiation (Philips Cleo Performance 40-W-R), performed under a lamp field at a distance of $12 \mathrm{~cm}\left(12 \mathrm{~mW} \cdot \mathrm{cm}^{-2}\right)$ for different times, led to the degradation of the stearic acid film. During irradiation, the samples were turned upside-down to have the same irradiation time for both sides. The peak intensities were controlled in appropriate time intervals.

\section{Conclusions}

Firing a single dip-coat of a ceria-bearing silica sol on soda-lime glass can lead to a three-layered $\mathrm{CeO}_{2} / \mathrm{SiO}_{2} / \mathrm{CeO}_{2}$ architecture of a self-assembled ceria crystallization in a $120 \mathrm{~nm}$ thin film on solar glass. Ceria crystallization at the interfaces with the soda-lime glass and the amorphous silica is probably a result of the strong ceria-silica interaction initiated by attractive forces of the nanoparticles of opposite surface charge during drying of the colloidal suspension.

The triple-layered structure of the coating enables combined photocatalytic and antireflective functionality. In particular, ceria crystals at the interface with the soda-lime glass act as a $\mathrm{Na}^{+}$migration barrier, ceria crystals at the surface are present in high concentrations for photooxidation processes, and the sequence of high/low/high refractive index materials allows for optical interference sustaining the AR function.

Author Contributions: Gundula Helsch conceived, designed and performed the experiments; Gundula Helsch and Joachim Deubener analyzed the data and wrote the paper.

Conflicts of Interest: The authors declare no conflict of interest.

\section{References}

1. Deubener, J.; Helsch, H.; Moiseev, A.; Bornhöft, H. Glasses for solar energy conversion systems. J. Eur. Ceram. Soc. 2009, 29, 1203-1210. [CrossRef]

2. Cathro, K.; Constable, D.; Solaga, T. Silica low-reflection coatings for collector covers by a dip-coating process. Sol. Energy 1984, 32, 573-579. [CrossRef] 
3. Helsch, G.; Krzyzak, M.; Heide, G.; Frischat, G.H. Adherent antireflection coatings on borosilicate glass for solar collectors. Glass Technol. Eur. J. Glass Sci. Technol. A 2006, 47, 153-156.

4. Gombert, A.; Gaubitt, W.; Rose, K.; Dreibholz, J.; Blasi, B.; Heinzel, A.; Sporn, D.; Doll, W.; Wittwer, V. Antireflective transparent covers for solar devices. Sol. Energy 2000, 68, 357-360. [CrossRef]

5. Helsch, G.; Mös, A.; Deubener, J.; Höland, M. Thermal resistance of nanoporous antireflective coatings on silica glass for solar tower receivers. Sol. Energy Mater. Sol. Cells 2010, 94, 2191-2197. [CrossRef]

6. Zhang, X.; Sato, O.; Taguchi, M.; Einaga, Y.; Murakami, T.; Fujishima, A. Self-cleaning particle coating with antireflection properties. Chem. Mater. 2005, 17, 696-700. [CrossRef]

7. Zhang, X.; Fujishima, A.; Jin, M.; Emeline, A.V.; Murakami, T. Double-layered $\mathrm{TiO}_{2}-\mathrm{SiO}_{2}$ nanostructured films with self-cleaning and antireflective properties. J. Phys. Chem. B 2006, 110, 25142-25148. [CrossRef] [PubMed]

8. Liu, Z.; Zhang, X.; Murakami, T.; Fujishima, A. Sol-gel $\mathrm{SiO}_{2} / \mathrm{TiO}_{2}$ bilayer films with self-cleaning and antireflection properties. Sol. Energy Mater. Sol. Cells 2008, 92, 1434-1438. [CrossRef]

9. Kesmez, Ö.; Camurlu, H.E.; Burunkaya, E.; Arpac, E. Sol-gel preparation and characterization of antireflective and self-cleaning $\mathrm{TiO}_{2}-\mathrm{SiO}_{2}$ double-layer nanometric films. Sol. Energy Mater. Sol. Cells 2009, 93, 1833-1839. [CrossRef]

10. Faustini, M.; Nicole, L.; Boissiere, C.; Innocenzi, P.; Sanchez, C.; Grosso, D. Hydrophobic, antireflective, self-cleaning, and antifogging sol-gel coatings: An example of multifunctional nanostructured materials for photovoltaic cells. Chem. Mater. 2010, 22, 4406-4413. [CrossRef]

11. Burunkaya, E.; Kesmez, Ö.; Kiraz, N.; Camurlu, H.E.; Asiltürk, M.; Arpac, E. Sn ${ }^{4+}$ or $\mathrm{Ce}^{3+}$ doped $\mathrm{TiO}_{2}$ photocatalytic nanometric films on antireflective nano- $\mathrm{SiO}_{2}$ coated glass. Mater. Chem. Phys. 2010, 120, 272-276. [CrossRef]

12. Prado, R.; Beobide, G.; Marcaide, A.; Goikoetxea, J.; Aranzabe, A. Development of multifunctional sol-gel coatings: Anti-reflection coatings with enhanced self-cleaning capacity. Sol. Energy Mater. Sol. Cells 2010, 94, 1081-1088. [CrossRef]

13. Helsch, G.; Deubener, J. Compatibility of antireflective coatings on glass for solar applications with photocatalytic propertires. Sol. Energy 2012, 86, 831-836. [CrossRef]

14. Jiang, B.; Zhang, S.; Guo, X.; Jin, B.; Tian, Y. Preparation and photocatalytic activity of $\mathrm{CeO}_{2} / \mathrm{TiO}_{2}$ interface composite film. Appl. Surf. Sci. 2009, 255, 5975-5978. [CrossRef]

15. Özer, N. Optical properties and electrochromic characterization of sol-gel deposited ceria films. Sol. Energy Mater. Sol. Cells 2001, 68, 391-400. [CrossRef]

16. Channei, D.; Nakaruk, A.; Phanichphant, S.; Koshy, P.; Sorrell, C.C. Effect of iron doping on the structural and optical properties of $\mathrm{CeO}_{2}$ films. J. Sol-Gel Sci. Technol. 2016, 79, 51-58. [CrossRef]

17. Khan, S.B.; Faisal, M.; Rahman, M.M.; Jamal, A. Exploration of $\mathrm{CeO}_{2}$ nanoparticles as a chemi-sensor and photo-catalyst for environmental applications. Sci. Total Environ. 2011, 409, 2987-2992. [CrossRef] [PubMed]

18. Sifontes, A.B.; Rosales, M.; Méndez, F.J.; Oviedo, O.; Zoltan, T. Effect of Calcination Temperature on Structural Properties and Photocatalytic Activity of Ceria Nanoparticles Synthesized Employing Chitosan as Template. J. Nanomater. 2013, 2013, 265797. [CrossRef]

19. Arul, N.S.; Mangalaraj, D.; Chen, P.C.; Ponpandian, N.; Meena, P.; Masuda, Y. Enhanced photocatalytic activity of cobalt-doped $\mathrm{CeO}_{2}$ nanorods. J. Sol-Gel Sci. Technol. 2012, 64, 515-523. [CrossRef]

20. Yu, Y.; Zhu, Y.; Meng, M. Preparation, formation mechanism and photocatalysis of ultrathin mesoporous single-crystal-like $\mathrm{CeO}_{2}$ nanosheets. Dalton Trans. 2013, 42, 12087-12092. [CrossRef] [PubMed]

21. Qian, J.; Chen, F.; Wang, F.; Zhao, X.; Chen, Z. Daylight photocatalysis performance of biomorphic $\mathrm{CeO}_{2}$ hollow fibers prepared with lens cleaning paper as biotemplate. Mater. Res. Bull. 2012, 47, 1845-1848. [CrossRef]

22. Arul, N.S.; Mangalaraj, D.; Kim, T.W. Solvothermal synthesis of hierarchically porous $\mathrm{CeO}_{2}$ nanopalm leaves and their photocatalytic properties. J. Sol-Gel Sci. Technol. 2013, 66, 15-21. [CrossRef]

23. Krogman, K.C.; Druffel, T.; Sunkara, M.K. Anti-reflective optical coatings incorporating nanoparticles. Nanotechnology 2005, 16, 338-343. [CrossRef] [PubMed]

24. Pepe, A.; Aparicio, M.; Cere, S.; Duran, A. Preparation and characterization of cerium doped silica sol-gel coatings on glass and aluminum substrates. J. Non-Cryst. Solids 2004, 348, 162-171. [CrossRef]

25. Garcia-Heras, M.; Jimenez-Morales, A.; Casal, B.; Galvan, J.C.; Radzki, S.; Villegas, M.A. Preparation and electrochemical study of cerium-silica sol-gel thin films. J. Alloy. Compd. 2004, 380, 219-224. [CrossRef] 
26. Nocun, M.; Burcon, D.; Siwulski, S. Sodium diffusion barrier coatings prepared by sol-gel method. Opt. Appl. 2008, 38, 171-179.

27. Matthias, A.; Raićevic, N.; Donfeu Tchana, R.; Kip, D.; Deubener, J. Density dependence of refractive index of nanoparticle-derived titania films on glass. Thin Solid Films 2014, 558, 86-92. [CrossRef]

28. Rupp, J.L.M.; Solenthaler, C.; Gasser, P.; Muecke, U.P.; Gauckler, L.J. Crystallization of amorphous ceria solid solutions. Acta Mater. 2007, 55, 3505-3512. [CrossRef]

29. Rupp, J.L.M.; Scherrer, B.; Schäuble, N.; Gauckler, L.J. Time-temperature-transformation (TTT) diagrams for crystallization of metal oxide thin films. Adv. Funct. Mater. 2010, 20, 2807-2814. [CrossRef]

30. Rupp, J.L.M.; Scherrer, B.; Gauckler, L.J. Engineering disorder in precipitation-based nano-scaled metal oxide thin films. Phys. Chem. Chem. Phys. 2010, 12, 11114-11124. [CrossRef] [PubMed]

31. Jiang, P.; Bertone, J.F.; Hwang, K.S.; Colvin, V.L. Single-crystal colloidal multilayers of controlled thickness. Chem. Mater. 1999, 11, 2132-2140. [CrossRef]

32. Dziomkina, N.V.; Vancso, G.S. Colloidal crystal assembly on topologically patterned templates. Soft Matter 2005, 1, 265-279. [CrossRef]

33. Kirby, B.J.; Hasselbrink, E.F. Zeta potential of microfluidic substrates: 1. Theory, experimental techniques, and effects on separations. Electrophoresis 2004, 25, 187-202. [CrossRef] [PubMed]

34. Dultz, S.; Behrens, H.; Helsch, G.; Deubener, J. Electrolyte effects on surface chemistry of basaltic glass in the initial stages of dissolution. Chem. Geol. 2016, 426, 71-84. [CrossRef]

35. Lin, X.Y.; Farhi, E.; Arribart, H. Determination of the isoelectric point of planar oxide surfaces by a particle adhesion method. J. Adhes. 1995, 51, 181-189. [CrossRef]

36. Patil, S.; Sandberg, A.; Heckert, E.; Self, W.; Seal, S. Protein adsorption and cellular uptake of cerium oxide nanoparticles as a function of zeta potential. Biomaterials 2007, 28, 4600-4607. [CrossRef] [PubMed]

37. Paz, Y.; Heller, A. Photo-oxidatively self-cleaning transparent titanium dioxide films on soda lime glass: The deleterious effect of sodium contamination and its prevention. J. Mater. Res. 1997, 12, 2759-2766. [CrossRef]

38. Watanabe, T.; Fukayama, S.; Miyauchi, M.; Fujishima, A.; Hashimoto, K. Photocatalytic activity and photo-induced wettability conversion of $\mathrm{TiO}_{2}$ thin film prepared by sol-gel process on a soda-lime glass. J. Sol-Gel Sci. Technol. 2000, 19, 71-76. [CrossRef]

39. Kennedy, E.M.; Cant, N.W. Oxidative dehydrogenation of ethane and the coupling of methane over sodium containing cerium oxides. Appl. Catal. A Gen. 1992, 87, 171-183. [CrossRef]

40. Kenanakis, G.; Katsarakis, N. Light-induced photocatalytic degradation of stearic acid by $c$-axis oriented ZnO nanowires. Appl. Catal. A Gen. 2010, 378, 227-233. [CrossRef]

(C) 2017 by the authors. Licensee MDPI, Basel, Switzerland. This article is an open access article distributed under the terms and conditions of the Creative Commons Attribution (CC BY) license (http://creativecommons.org/licenses/by/4.0/). 